\title{
Contrastive Analysis of Japanese and Indonesian Passive Sentences
}

\section{Dedi Sutedi}

Department of Japanese Language, Faculty of Languages Education, Universitas Pendidikan Indonesia Jl. Dr. Setiabudhi No. 229 Bandung, 40154 Jawa Barat, Indonesia; Email: dedisu2014@gmail.com

\section{Doi:10.5901/mjss.2016.v7n1s1p317}

\section{Abstract}

This study describes the similarities and differences between Japanese and Indonesian passive sentences through a pairing technique. Passive sentences in both languages are classified into several types based on their syntactic functions and categories and the semantic roles in 21 types of Japanese passive (JP) sentences and 22 types of Indonesian passive (IP) sentences. The findings show that all types of Japanese direct passive (CJ) sentences can be paired directly with the Indonesian di-V construction. Some of the Japanese indirect passive $(K J)$ sentences can be integrated into the constructions di-V, ter-V, ke-|-an, and construction ditinggal-V-intr, while others could not be paired with Indonesian passive sentences at all but could be expressed by active sentences with Indonesian words that convey opposing meanings. In contrast, the process of pairing Indonesian passive sentences with their Japanese counterparts indicates that type A9, personal passive, and some ter$\checkmark$ constructions could not be paired with Japanese passive sentences but could be expressed through active sentences by putting the object in front.

Keywords: Direct passive, indirect passive, di-V construction, ke-|-an construction, adversative

\section{Introduction}

Indonesian learners and teachers of the Japanese language find it hard to learn Japanese passive sentences due to the wide variations between the two languages, such as meaning and function (in terms of sentence formation). The predicate of a Japanese passive sentence can be filled by transitive, ditransitive, and intransitive verbs, whereas the predicate in Indonesian passive sentences can only be filled by transitive and ditransitive verbs. Similarly, in Japanese, inanimate nouns cannot freely constitute the subject, due to the binding rules in Japanese grammar, whereas, in Indonesian, inanimate nouns can freely constitute the subject. A passive function in Japanese serves to express a special case, though it is limited in scope, while in Indonesian, the use of passives is much more freely applied and is thus more flexible.

Japanese teachers often find it difficult to explain passive sentences that have the same syntactic functions and category and yet are acceptable in one case and not acceptable in another case, as we can see in the following examples:

- Kono hon wa tennou heika ni yom-are-te iru.

this book-NP1 His Highness the Emperor-NP2 read-pass-past.

'This book is read by His Highness the Emperor.'

- *Kono hon wa Tarou ni yom-are-te iru.

this book-NP1 Taro-NP2 read-pass-past.

'This book is read by Taro.'

- Kono hon wa Tarou ni yabur-are-ta.

this book-NP1 Taro-NP2 tear-pass-past.

'This book is torn by Taro.'

The three sentences in the above construction have the same syntactic function and category, but sentences (1) and (3) are acceptable while sentence (2) is not acceptable. This difference is because of the semantic role and type of verb in the predicate; hence, the sentences should be sorted into different types. The Indonesian grammar and syntax rules are one of the primary reasons why an Indonesian student has difficulty learning and using Japanese passive sentences correctly (Tanaka, 1991; Sutedi, 2006). This difficulty is revealed in the following examples:

- $\quad$ *Kono hon wa watashi ni yom-are-te iru.

this book-NP1 I-NP2 read-pass-past.

'This book, that I read.' 
- *Watashi no raburetaa wa haha ni yom-are-te iru.

my love letter-NP1 mother-NP2 read-pass-past.

'My love letter was read by mother.'

- "Kono mizu wa nom-are-te mo ii.

this water-NP1 drink-pass-Mod.

'This water can be drink.'

- Watashi wa Yamamoto sensei ni nihongo wo oshier-are-ta.

I-NP1 Mr. Yamamoto-NP2 Japanese-FN3 teach-pass-past.

'I was taught Japanese by Mr. Yamamoto.'

The mistakes in examples (4)-(6) emerge due to the Indonesian language interference, whereas example (7) presents an acceptable construction but conveys an improper meaning and context. Mr. Yamamoto, as a native Japanese speaker, would feel uncomfortable or may even be offended upon hearing those sentences, although, for Indonesian learners, those sentences would sound polite and grateful. This scenario is one of the major differences in passive sentence functions found in Japanese and Indonesian.

One of the ways to overcome the above problems is to describe the similarities and differences in the passive sentence patterns of both languages. Therefore, I have conducted an analysis contrasting Japanese and Indonesian passive sentences. This contrastive analysis looked at the syntactic functions and categories, as well as the semantic roles, of passive sentences in both languages, with reference to the opinions of Verhaar $(1982,2004)$; Kridalaksana (1986, 2002); Tsunoda (1991); Muraki (1996, 2004); Hasegawa (1999), and Nakano (2012).

This study was conducted in four steps. First, a review of previous studies was conducted to sort Japanese and Indonesian passive sentences into several types based on their syntactic categories and functions, as well as their semantic roles. For Japanese passive sentences, the studies reviewed were those conducted by Nitta $(1979,2011)$; Takami (1997, 2011); Teramura (2002), and Takahashi (2006), while for the Indonesian passives, the previous studies reviewed were those of Kaswanti (1984, 1986, 1989, 2000); Sugono (1991), and Alwi (2006). Muraki's (1996, 2004) method for describing semantic roles was also used. Second, Japanese and Indonesian passive sentences were paired to find corresponding and non-corresponding types. Third, the different types of Indonesian patterns were integrated into Japanese passive sentences to find corresponding and non-corresponding types. Fourth, the presentation order of passive sentence materials to Japanese learners in Indonesia was determined. However, in this paper, only three steps are discussed.

\section{Types of Japanese and Indonesian Passive Sentences}

Japanese passive sentences are categorized into direct passive (chokusetsu judoubun/CJ) and indirect passive (kansetsu judoubun/KJ) types. The predicate of a direct passive sentence can be formed of transitive and intransitive verbs, whereas the predicate of indirect passive sentences can be formed of transitive, ditransitive, and intransitive verbs. In this study, the sentences were sorted by syntactical functions and categories, as well as semantic roles. Direct passive sentences that have transitive verbs as their predicate are classified into eight categories, types CJ1 through CJ8 (Sutedi, 2013), and those with ditransitive verbs are categorized into three types, CJ9 CJ11. On the other hand, indirect passive sentences are classified into 10 types, $\mathrm{KJ} 1 \sim \mathrm{KJ} 10$, and contain transitive, ditransitive, and intransitive verbs as predicates (Sutedi, 2012). Hence, Japanese passive sentences are classified into a total of 21 types.

Meanwhile, Indonesian passive sentences are categorized into five construction types: di-V construction (type A), personal passive (type B), ter-V construction (type C), ke-|-an construction (type D), and kena- construction (type E). With reference to the syntactic functions and categories, as well as the semantic roles, Indonesian passive sentences are classified into a total of 22 types: A1 A13 for di-V passive construction, B1 - B3 for personal passive, C1 and C2 for ter-V passive, D1 and D2 for ke-|-an passive, and E1 and E2 for kena-passive. Examples of each type of Japanese and Indonesian passive sentence are presented in Table 1:

Table 1. Types of Passive Sentences in Japanese and Indonesian

\begin{tabular}{|c|c|l|c|l|}
\hline No & TP & Example of Passive Japanese (JP) & TP & Example of Passive Indonesia (IP) \\
\hline 1 & CJ1 & Jirou wa Tarou ni nagurareta. & A1 & Ali dipukul oleh Amir. \\
\hline 2 & CJ2 & Kono hon wa Tarou ni yaburareta. & A2 & Buku ini dirobek oleh Amir. \\
\hline 3 & CJ3 & Kenkyuu keikaku wa sinsain ni mitomerareta. & A3 & Proposal itu telah disetujui oleh tim penilai. \\
\hline 4 & CJ4 & Kono uta wa Nagabuchi ni utawarete, hitto songu ni natta. & A4 & Lagu ini dinyanyikan oleh Iwan Fals. \\
\hline
\end{tabular}




\begin{tabular}{|l|l|l|l|l|}
5 & CJ5 & Kono uta wa wakamono ni aisarete iru. & A5 & Lagu ini dicintai oleh mayoritas anak muda. \\
\hline 6 & CJ6 & Nihon wa umi ni kakomarete iru. & A6 & Jepang dikelilingi oleh lautan. \\
\hline 7 & CJ7 & Kono kikai wa chuugakusei ni yotte tsukurareta. & A7 & Mesin ini dibuat oleh siswa SMP. \\
\hline 8 & CJ8 & Kokusai kaigi ga okonawareta. & A8 & Konferensi internasional telah diselenggarakan. \\
\hline 9 & CJ9 & Hanako wa Tarou ni sono shorui wo watasareta. & A9 & Buku itu selalu dibaca oleh ibu. \\
\hline 10 & CJ10 & Sono shorui wa Tarou kara Hanako ni watasareta. & A10 & Hanako diserahi dokumen itu oleh Taro. \\
\hline 11 & CJ11 & Hanako wa douryou ni 'Shokuba no hana da' to iwarete iru. & A11 & $\begin{array}{l}\text { Dokumen itu diserahkan dari Taro pada } \\
\text { Hanako. }\end{array}$ \\
\hline 12 & KJ1 & Watashi wa tonari no hito ni ashi wo fumareta. & A12 & $\begin{array}{l}\text { Dia dijuluki dengan 'Bunga Desa' oleh teman } \\
\text { kerjanya. }\end{array}$ \\
\hline 13 & KJ2 & Chichi wa musuko ni yoru osoku made gitaa wo hirakareta. & A13 & Saya ditinggal mati oleh ayah. \\
\hline 14 & KJ3 & $\begin{array}{l}\text { Watashi wa Tarou ni tatta hitotu no daijina shorui wo Hanako ni } \\
\text { watasareta. }\end{array}$ & B1 & Buku ini sudahsaya baca. \\
\hline 15 & KJ4 & Kodomo-tachi wa ame ni furareta. & B2 & Buku ini belum kau baca. \\
\hline 16 & KJ5 & Watashi wa chichi ni shinareta. & B3 & Buku ini sedang dia baca. \\
\hline 17 & KJ6 & Watashi wa tonari no hito sawagarete benkyou dekinakatta. & C1 & Kaki saya terinjak oleh teman. \\
\hline 18 & KJ7 & Watashi wa kodomo ni soba ni irarete tabako ga suenaku natta. & C2 & Soal matematika itu terjawab oleh adik. \\
\hline 19 & KJ8 & Watashi wa tsuma ni jikka e kaerarete komatte iru. & D1 & Anak-anak kehujanan. \\
\hline 20 & KJ9 & $\begin{array}{l}\text { Haha wa tonari no kodomo ni souji shita bakari no yuka wo } \\
\text { arukareta. }\end{array}$ & D2 & Tangisannya kedengaran oleh kami. \\
\hline 21 & KJ10 & Chichi wa musume ni moderu ni narareta. & E1 & Anak-anak kena hujan. \\
\hline 22 & & & E2 & Dia kena tampar ayahnya. \\
\hline
\end{tabular}

\section{Pairing Japanese into Indonesian Passive Sentences}

Contrasting Japanese and Indonesian passive sentences was conducted by searching for each type of Japanese passive sentence to pair into an Indonesian type, and vice versa. The pairing results of Japanese into Indonesian revealed that there are correspondences between some passive sentence types, although some types were not able to be paired to a passive Indonesian sentence type. The following are the results of the process of pairing Japanese passive sentences into Indonesian (the sign $\rightarrow$ shows the revealed pairs in Indonesian).

The characteristics of the CJ1 passive sentence type are that NP1 and NP2 are filled by animate nouns, each of which plays objective $(0)$ and agentive $(A)$ semantic roles, while the predicative verb is filled by a volitional action. This passive type corresponds to the A1 type in Indonesian, as seen in the following example:

\section{- Jirou wa Tarou ni nagur-are-ta. (CJ1) \\ Jiro-NP1-O Taro-NP2-A hit-pass-past. \\ Jiro was hit by Taro.' \\ $\rightarrow$ Jiro dipukul oleh Taro. (A1) \\ Jiro-NP1-O di-hit by Taro-NP2-A \\ 'Jiro was hit by Taro.'}

The characteristics of the CJ2 passive sentence types are that NP1 is filled by inanimate nouns that acts as an objective change (Oc), NP2 is filled by animate nouns, and the predicate is filled by the volitional verb that means destruction. This passive type corresponds to type A2 in Indonesian:

- Kono doa ga Tarou ni kowas-are-ta. (CJ2)

this door-NP1-Oc Taro-NP2-A break-pass-past.

'This door was broken by Taro.'

$\rightarrow$ Pintu ini dirusak oleh Taro. (A2)

this door-NP1-Oc di-break by Taro-NP2-A

'This door was broken by Taro.'

The characteristics of the CJ3 type are that NP1 is an inanimate noun that acts as an objective change (Oc), NP2 is filled by an animate noun, and the predicate is filled by the volitional action verb that means beneficial or increases the value of NP1. This corresponds to the passive type A3 in Indonesian:

- Kenkyuu keikaku wa shinsain ni mitomer-are-ta. (JP: CJ3)

the research proposal-NP1-Oe assessor-NP2-A approve-pass-past.

'The research proposal was approve by the assessor.'

$\rightarrow$ Proposal penelitian telah disetujui oleh tim penilai. (IP: A-3) 
the research proposal-NP1-Oe past di-approve by team of assessors-NP2-A

'The research proposal was approvedby the team of assessors.'

The characteristics of the CJ4 passive sentence type are that NP1 is an inanimate noun, NP2 is a noun that indicates a famous person, and the predicative verb is filled by a volitional action. This corresponds to the passive A4 type in Indonesian:

- Kono uta wa Nagabuchi ni utaw-are-te, hitto songu ni natta. (CJ4)

this song-NP1-Oc Nagabuchi-NP2-A sing-pass become popular

This song becomes popular after being sung by Nagabuchi.'

$\rightarrow$ 'Lagu ini menjadi terkenal setelah dinyanyikan oleh Nagabuchi.' (IP: A4)

this song-NP1-Oc becomes popular di-sing by NP2-A

'This song became popular after being sung by Nagabuchi.'

The characteristics of the CJ5 passive sentence type are that NP1 is an inanimate noun, NP2 is an animate noun disguised as an inanimate noun and the predicative verb is filled by a volitional action. This corresponds to the passive A5 type in Indonesian:

- Kono uta wa wakamono ni ais-are-te iru. (JP: CJ5)

this song-NP1-O young people-NP2-A love-pass-asp.

'This song is loved by young people.'

$\rightarrow$ Lagu ini dicintai oleh kaula muda. (IP: A5)

this song-NP1-Oe di-love by young people-NP2-A

'This song is loved by young people.'

The characteristics of the CJ6 passive sentence type are that NP1 and NP2 are inanimate nouns, the semantic role of NP2 is locative $(L)$ or instrumental $(I)$, and the predicative verb is filled by stating the circumstances presented in the form of resultant aspects. This corresponds to the passive A6 type in Indonesian:

- Nihon wa umi ni kakom-are-te iru. (JP: CJ6)

Japan-NP1-O sea-NP2-L surround-pass-asp.

'Japan is surrounded by sea.'

$\rightarrow$ Jepang dikelilingi oleh lautan. (IP: A6)

Japan-NP1-O di-surround sea-NP2-L

'Japan is surrounded by sea.'7.

The characteristics of the CJ7 passive sentence type are that NP1 is an inanimate noun that acts as an objective effective (Oe), NP2 is an animate noun that is followed by the NI YOTTE particle, and the predicate is filled by a volitional verb that means to do or to create NP1. This corresponds to the passive A7 type in Indonesian:

- Kono kikai wa chuugakusei ni yotte tsukur-are-ta. (CJ7)

this machine-NP1-Oe Junior High students-NP2-A build-pass-past.

'This machine was builtby Junior High students.'

$\rightarrow$ Mesin ini dibuat oleh siswa SMP. (IP: A7)

machine-NP1-Oe di-build by Junior high student-NP2-A

'This machine was built by Junior High students.'

The characteristics of the CJ8 passive sentence type are that NP1 is filled by either animate or inanimate nouns, NP2 is an animate noun but not shown, and the predicate is filled by a volitional action. This corresponds to the passive A8 type in Indonesian:

- Kokusai-kaigi ga okonaw-are-ta. (CJ8)

International Conference-NP1-O hold-pass-past.

'The international conference had been held.'

$\rightarrow$ Konferensi internasional telah diselenggarakan. (A8)

International confeence-NP1-O past di-hold

'The international conference had been held.'

Based on the above examples, it can be seen that the Japanese direct passive sentences with transitive verbs of the CJ1 CJ8 types can be paired into Indonesian passive sentences of the A1 A8 construction types, respectively. This is possible because the syntactic category and the semantic role in each of these Japanese and Indonesian passive sentence types are the same.

The following are the resultant pairs of Japanese direct passive sentences with predicates consisting of ditransitive verbs (type CJ9 CJ11) into Indonesian. 
The characteristics of the CJ9 passive sentence type are that NP1 and NP2 are animate nouns, NP3 is a noun (animate or inanimate), and the predicate is filled by a ditransitive verb that represents a volitional action. This type can be paired with the Indonesian passive A10 type:
- Hanako wa Tarou ni sono shorui wo watas-are-ta. (CJ9)
Hanako-NP1-G Taro-NP2-A that document-NP3-O give-pass-past.
'Hanako was given that document by Taro.'
$\rightarrow$ Hanako diserahi dokumen itu oleh Taro. (IP: A10)
Hanako-NP1-G di-give document-NP3-O by Taro-NP2-A
'Hanako was given that document by Taro.'

The characteristics of the CJ10 passive sentence type are that NP1 is an inanimate noun, NP2 and NP3 are animate or inanimate nouns, each of which act as source $(\mathrm{S})$ and means $(\mathrm{G})$, and the predicate is filled by a ditransitive verb that represents a volitional action. This type can be paired with the Indonesian passive A11 type:

- Sono shorui wa Tarou kara Hanako ni watas-are-ta. (CJ10) that document-NP1-O Taro-NP2-S Hanako-NP3-G give-pass-past.

'That document was givenfrom Taro to Hanako.'

$\rightarrow$ Dokumen itu diserahkan dari Taro pada Hanako. (IP: A11)

that document-NP1-O di-give from Taro-NP3-S to Hanako-NP2-G

'That document was givenfrom Taro to Hanako.'

The characteristics of the CJ11 passive sentence type are that NP1 is an animate or inanimate noun, NP2 is a human, NP3 can take the form of a clause or a sentence that acts as content (Ct), and the predicate is filled by a verb that can follow the particle TO. This passive type can be paired with the Indonesian passive A12 type:

- Hanako wa douryou ni 'Shokuba no hana da' to iw-are-te iru.

Hanako-NP1-O co-workers-NP2-A office flower-NP3-Ct call-pass-asp.

'Hanako was called 'the Office Flower' by her co-workers.'

$\rightarrow$ Hanako dijuluki sebagai 'Bunga Kantor' oleh rekan kerjanya. (A-12)

Hanako-NP1-G di-call NP3-Ct by co workers-NP2-A

'Hanako was called 'the Office Flower' by her co-workers.'

Based on the above examples, it can be concluded that Japanese direct passive sentences with ditransitive verbs in the predicate can be paired with the di-V construction type in Indonesian. The following constructions are paired indirect passive sentences with transitive, ditransitive, or intransitive verbs in the predicate.

The KJ1 passive sentence type is an adversarial passive sentence that presents ownership (shoyuu) where NP1 is a noun of the owner, NP2 is an animate noun, NP3 is a nominal form of the owned, and the predicate is filled by a transitive verb that represents an action. This type can be paired with the Indonesian passive A1 and C1 types:
- Watashi wa hito ni ashi wo fum-are-ta.
I-NP1-Ea someone-NP2-A foot-NP3-O step-pass-past.
'My foot was stepped (upon)by someone.'

$\rightarrow$ Kaki saya diinjak oleh orang. (IP: A1)

My foot-NP3(NP1)-O di-step by someone-NP2-A

'My foot was stepped (upon)by someone.'

$\rightarrow$ Kaki saya terinjak oleh orang. (IP: C1)

My foot-NP3-NP1-O ter-step by someone-NP2-A (be unintentionally)

'My foot was unintentionally stepped (upon)by someone.'

This Japanese KJ1 type can be paired into the Indonesian A1 type if NP2 is considered to be acting intentionally and the Indonesian type C1 if NP2 is considered to be acting unintentionally.

The KJ2 type is a non-owner adversarial passive sentence (shoyuu igai) where NP1 and NP2 are animate nouns, NP3 is a noun, and the predicate is filled by a verb that expresses an action. This type cannot be paired with an Indonesian passive type:

- Chichi wa musuko ni yoru osoku made gitaa wo hik-are-ta. (KJ2)

father-NP1-Ea child-NP2-A late at night guitar-NP3-O play-pass-past.

'Child played guitar; father was negatively affected by it.'

$\rightarrow$ Ayah terganggu karena anak laki-laki memainkan gitar sampai malam. (act)

father-NP1-Ea son-NP2-A play-act guitar-NP3-O night

'Father was bothered because his son played guitar till late at night.'

The examples above show that the Japanese KJ2 type cannot be paired into an Indonesian passive sentence. 
Therefore, it should be paired with a passive sentence that uses words that convey negative (emotional) meanings, such as terganggu (disturbed/ bothered), tidak suka (dislike), menderita (suffer), kecewa (disappointed), etc.

The KJ3 type is an indirect passive sentence that originates from a ditransitive sentence:

- Watashi wa Tarou ni daijina shorui wo Hanako ni watas-are-ta. (KJ3)

I-NP1-Ea Taro-NP2-A important doc-NP3-O Hanako-NP4-G give-pass-past.

'I was disappointed, because Taro gave important document to Hanako.'

$\rightarrow$ Saya kecewa karena Taro menyerahkan dokumen penting pada Hanako.

I-NP1-Ea Taro-NP2-A give document -NP3-O to Hanako-NP4-G

'I was disappointed, because Taro gave important document to Hanako.'

The following description presents Japanese indirect passive sentences with intransitive verbs in the predicate contrasted with Indonesian patterns:

The KJ4 type is an indirect passive sentence stating a natural event. NP1 is an animate noun, NP2 is a natural phenomenon, and the predicate is filled by an intransitive verb. This type can be paired with the Indonesian passive $\mathrm{C} 1$ type:

- Kodomo-tachi ga ame ni fur-are-ta. (KJ4) children-NP1-Ea rain-NP2-A fall-pass-past.

'The children were affected by the rain.'

$\rightarrow$ Anak-anak kehujanan. (IP: C1)

children-NP1-Ea ke-rain-an

'The children were affected by the rain.'

The KJ5 type is an indirect passive sentence where NP1 is an animate noun, NP2 is an animate noun, and the predicate is filled by an intransitive verb that means disappearing from the usual place. This type can be paired with the Indonesian passive A13 type:

- Watashi wa chichi ni shin-are-ta.

I-NP1-Ea father-NP2-E die-pass-past.

'I lost my father.'

$\rightarrow$ Saya ditinggal mati oleh ayah. (IP: type A-13)

I-NP1-Ea left die by father-NP2-E

'I lost my father.'

The KJ6 type is an indirect passive sentence that originates from a regular intransitive sentence. NP1 is a personal noun, NP2 is a noun, and the predicate is filled by an intransitive verb:

- Watashi wa tonari no hito ni sawag-are-te, benkyou dekinakatta.

I-NP1-Ea neighbors-NP2-A noisy-pass. cannot study

'I can not study, because the neighbors' are noisy.'

$\rightarrow$ Saya terganggu tidak bisa belajar, karena tetangga pada ribut. (Active)

I-NP1-Ea can not study because neighbors-NP2-A noisy.

'I cannot study, because the neighbors are noisy.'

The KJ7 type is an indirect passive sentence that states presence. NP1 is a human being, NP2 is an animate noun, NP3 is a place, and the predicate is filled by the IRU verb 'there':

- Watashi wa kodomo ni soba ni ir-are-te, tabako ga suenaku natta.

I-NP1-Ea child-NP2-A side-NP3-L there-pass can not smoke

'I cannot smoke, because my child is (there) by my side.'

$\rightarrow$ Saya terganggu tidak bisa merokok, karena anak berada di samping saya. (act)

I-NP1-Ea cannot smoke because, child-NP2-A by side-NP2-L

'I cannot smoke, because my child is by my side.'

The KJ8 type is an indirect passive sentence where NP1 and NP2 are human beings, NP3 is a destination, and the predicate is filled by an intransitive verb stating a displacement:

- Watashi wa tsuma ni jikka e kaer-are-te, komatte iru.

I-NP1-Ea wife-NP2-A parents' house-NP3-G go home-pass left

'I was left by my wife's going home to her parents' house.'

$\rightarrow$ Saya ditinggal pulang oleh istri ke rumah orang tuanya. (Active)

I-NP1-Ea was left-go home -akt wife-NP2-A parents' house-NP3-G

'I was left by my wife's going home to her parents' house.' 
The KJ9 type is an indirect passive sentence where NP1 and NP2 are animate nouns, NP3 is a path, and the predicate is filled by an intransitive verb that states movement:

- Haha wa tonari no kodomo ni souji shita bakari no yuka wo aruk-are-ta.

mother-NP1-Ea neighbors'kid-NP2-A recently floor-NP3-O walk-pass-past.

'Mother is occupied, because the neighbors' kid walked on the recently mopped floor.'

$\rightarrow$ Ibu repot, karena anak tetangga berjalan di lantai yang baru dipel. (Active)

mother-NP1-Ea neighbors' kid -NP2-A recently mopped floor-NP3-O walk-active

'Mother is occupied, becausethe neighbors' kid walked on the recently mopped floor.'

The K10 type is an indirect passive sentence with the predicate filled by the NARU verb (to become):

- Chichi wa musume ni moderu ni nar-are-te, komatte iru.

father-NP1-Ea daughter-NP2-E model-NP3-G become-pass difficult

'Father is disappointed, becausehis daughter becomes a model.'

$\rightarrow$ Ayah kecewa, karena anak gadisnya menjadi seorang model. (Active)

father-NP1-Ea because her daughter pr.-NP2-E become-active model-NP3-G

'Father is disappointed, becausehis daughter becomes a model.'

Thus, the process of paring each type of Japanese passive sentence into Indonesian has resulted in some paired and some unpaired passive sentences in Indonesian. The 21 Japanese types paired into Indonesian can be summarized in Table 2:

Table 2: Japanese passive sentence structures paired into Indonesian patterns

\begin{tabular}{|c|c|c|c|}
\hline TP & Passive $\mathrm{J}$ & TP & Passive I \\
\hline CJ1 CJ7 & NP1-wa---NP2-ni (yotte)----V-tr-areru & A1 A7 & NP1----di-V-tr-----(oleh)-NP2 \\
\hline CJ8 & NP1-wa------V-tr-areru & A8 & NP1---------di-V-tr \\
\hline CJ9 & NP1-wa---NP2-ni---NP3-wo---V-dit-areru & A10 & NP1----di-V-ditr----NP3---oleh-NP2 \\
\hline CJ10 & NP1-wa---NP2-kara---NP3-ni----V-ditr-areru & A11 & NP1----di-V-ditr----dari NP2----pada-NP3 \\
\hline CJ11 & NP1-wa---NP2-ni---NP3-to---V-tr-areru & A12 & NP1---di-V-tr---(dengan)-NP3---oleh NP3 \\
\hline KJ1 & NP1-wa----NP2-ni-----NP3-wo----V-tr-areru & D-1 & NP3-NP1-----di-V-tr----(oleh)-NP2 \\
\hline $\mathrm{KJ} 2$ & NP1-wa----NP2-ni-----NP3-wo----V-tr-areru & Active & NP1 kecewa/ terganggu/ menderita karena -----NP2----V-tr-----NP3 \\
\hline KJ3 & $\begin{array}{l}\text { NP1-wa----NP2-ni-----NP3-w0----NP4-ni------V-tr- } \\
\text { areru }\end{array}$ & Active & $\begin{array}{l}\text { NP1 kecewa/ terganggu/ menderita karena -----NP2----V-tr-----NP3----- } \\
\text { (pada)-NP4 }\end{array}$ \\
\hline KJ4 & NP1-wa----NP2-ni----V-intr-areru & D1 & NP1----ke-NP2-an \\
\hline KJ5 & NP1-wa----NP2-ni----V-intr-areru & A13 & NP1----ditinggal-V-intr----(oleh)-NP2 \\
\hline KJ6 & NP1-wa----NP2-ni----V-intr-areru & Active & NP1 kecewa/ terganggu/ menderita karena -----NP2-----V-intr \\
\hline KJ7 & NP1-wa----NP2-ni----NP3-ni---IRARERU & Active & NP1 kecewa/ terganggu/ menderita karena -----NP2----BERADA----di-NP3 \\
\hline KJ8 & NP1-wa----NP2-ni----NP3-e----V-intr-areru & A13 & NP----ditinggal-V-intr----(oleh)-NP2---- ke-NP3 \\
\hline KJ9 & NP1-wa----NP2-ni----NP3-wo----V-intr-areru & Active & NP1 kecewa/ terganggu/ menderita karena -----NP2-----V-intr----(di)-NP3 \\
\hline KJ10 & NP1-wa----NP2-ni-----NP3-ni----V-intr-areru & Active & NP1 kecewa/ terganggu/ menderita karena -----NP2-----menjadi----NP3 \\
\hline
\end{tabular}

This table shows that all types of direct passive sentences can be paired with the di-V construction in Indonesian. The passive sentence types $\mathrm{KJ} 2, \mathrm{KJ} 2, \mathrm{KJ} 6, \mathrm{KJ} 7, \mathrm{KJ}$, and $\mathrm{KJ} 10$ could not be paired into Indonesian passive structure. These types can cause difficulties for Indonesian students of the Japanese language.

\section{The Established Structures of Indonesian Passive Sentences Paired into Japanese Patterns}

This section presents the established structures of Indonesian passive sentences paired into Japanese passive sentences. There are some that can be paired into Japanese passive sentences, and there are also those that have to be paired into Japanese active sentences. The previous section presented 22 types of Indonesian passive sentences paired into Japanese as follows (sign $\rightarrow$ shows resulted pairs in Japanese).

The passive sentence A1-A8 types are paired with the Japanese direct passive sentence CJ1-CJ8 types, because their semantic functions, categories and roles are the same. In short, these types are paired with each other.

The Indonesian passive sentence A9 type is different from the previous types because the semantic role of NP1 takes the form of a regular objective (O), and so it cannot be paired with a Japanese passive sentence type. This type of passive can only be paired into Japanese active sentences, as seen in the following example:

- $\quad$ Majalah ini selalu dibaca oleh ibu. (IP: A9) 
magazine-NP1-O always di-read by mother-NP2-A

'This magazine is always read by mother.'

$\rightarrow$ *Kono zasshi wa itsumo haha ni yom-are-te iru. (JP: direct passive)

this magazine-NP1-O always mother-NP2-A read-pass

$\rightarrow$ Kono zasshi wa itsumo haha ga yon-de iru. (active)

this magazine-NP1-O always mother-NP2-A read-active-asp.

'This magazine, that mother always reads.'

Therefore, this Indonesian passive sentence A9 type can only be paired into active sentences by putting the object (NP1) in front.

The Indonesian passive sentence A10-A12 types can also be paired with Japanese passive sentence CJ9-CJ11

types. Thus, each type of passive sentence is paired with its counterpart in the other language.

The passive sentence B1, B2 and B3 types are personal passive in Indonesian and cannot be paired with any Japanese passive sentence type:

- Buku ini sudah saya baca. (IP)

book-NP1-O past. I-read

'This book I had read.'

$\rightarrow$ Kono hon wa, watashi ga yon-da. (active)

this book-NP1-O I-A read-active-past.

'This book I had read.'

- Buku ini sudah kamu baca. (IP)

book-NP1-O past. you-read

'This book you had read.'

$\rightarrow$ Kono hon wa, anata ga yon-da. (active)

this book-NP1-O you-A read-active-past..

'This book you had read.'

- Buku ini sudah dia baca. (IP)

book-NP1-O past. he-read

'This book he had read.'

$\rightarrow$ Kono hon wa, kare ga yon-da. (active)

this book-NP1-O he-A read-active-past.

'This book he had read.'

Based on the above examples, pairing Indonesian personal passive into Japanese can only be done by putting the object in front, followed by the subject and predicate, resulting in a Japanese active sentence type.

The $\mathrm{C} 1$ and $\mathrm{C} 2$ types are passive sentences with ter- $\mathrm{V}$ construction. As passive sentences, this construction has two meanings: (a) stating action beyond awareness (inadvertent), which belongs to the $\mathrm{C} 1$ type, and (b) stating the capability of action and having a similar meaning to the di-V construction, which belongs to the C2 type. The $\mathrm{C} 1$ type is paired with the KJ1 type, whereas the C2 type can only be paired with a potential sentence (kanou hyougen):

- Kaki saya terinjak oleh teman. (IP: C1)

my foot-NP1-O ter-stepped (upon) by friend-NP2-A

'My foot was stepped upon by a friend.'

$\rightarrow *$ Watashi no ashi wa tomodachi ni fum-are-ta. (JP: CJ1)

my foot-NP1-O friend-NP2-A step-pass-past.

$\rightarrow$ Watashi wa tomodachi ni ashi wo fum-are-ta. (JP: KJ1)

I-NP1-Ea friend-NP2-A foot-NP3-O step-pass-past.

'My foot was stepped (upon) by a friend.'

- Soal matematika itu ter-jawab oleh adik. (IP: C2)

the math problem-NP1-O ter-answered by little brother-NP2-A

'The math problem was answeredby little brother.'

$\rightarrow *$ Sono suugaku no mondai wa otouto ni kotaer-are-ta. (JP: CJ1)

the math problem -NP1-O little brother-NP2-A answer-pass-past.

$\rightarrow$ (Otouto niwa) sono suugaku no mondai ga kotaer-are-ta. (active/pot)

little brother-NP2-A that math problem -NP1-O answer-potential-past.

'Little brotherwas able to answer the math problem' 
The D1 and D2 types are passive sentences with ke-|-an construction. In this construction, there are two sorts of words in between: a noun in the D1 type and a verb in the D2 type. The D1 passive type is paired with the KJ4 passive type. The D2 type cannot be paired into any Japanese passive sentence but can be paired with an intransitive active sentence because the verb kedengaran acts as the intransitive verb kikoeru:

- Anak-anak ke-hujan-an. (IP: D1)

children-NP1-Oe di-rain-upon

'Children are affected by the rain.'

$\rightarrow$ Kodomo-tachi wa ame ni fur-are-ta. (JP: KJ4)

children-NP1-Oe rain-NP1-O fall-pass-past.

'Children are affected by the rain.'

- Tangisannya ke-dengar-an oleh kami. (IP: D2)

Her cry-NP1-O ke-heard-an by us-NP2-A

'Her cry was heardby us.'

$\rightarrow$ Kanojo no nakigoe ga kikoe-ta. (active)

Her cry-NP1-O (be) hear-active-intransitive-past.

'Her cry was heard.'

The E1 and E2 types are passive sentences with kena- (befallen) construction, which consists of two types: kena$\mathrm{N}$ construction (E1) and kena-V construction (E2). These passive types can be paired into the Japanese KJ4 and CJ1 passive types, respectively:

- Anak-anak kena hujan. (IP: E1)

children-NP1-Oe kena-affected by rain

'Children were affected by rain.'

$\rightarrow$ Kodomo-tachi wa ame ni fur-are-ta. (JP: KJ1)

children-NP1-Ea rain-NP2-A fall-pass-past.

'Children were affected by rain.'

- $\quad$ Dia kena tampar kakaknya. (IP: E2)

he-NP1-Oe kena-slapped by his older brother-NP2-A

'He was slappedby his older brother.'

$\rightarrow$ Kare wa oniisan ni nagur-are-ta. (JP: C-1)

he-NP1-O older brother-NP2-A slap-pass-past.

'He was slapped (by) his older brother.'

Thus, it can be concluded that most of the Indonesian passive structures can be paired into Japanese passive sentences, although some have to be paired into active sentences. Table 3 presents information regarding the structures of each Indonesian passive type that is paired into Japanese passive patterns:

Table 3. Indonesian Passive Structures Paired into Japanese Patterns

\begin{tabular}{|c|c|c|c|}
\hline TP & Passive I & TP & Passive J \\
\hline \begin{tabular}{|l} 
A1 \\
A7
\end{tabular} & NP1----di-V-tr-----(oleh)-NP2 & \begin{tabular}{|l} 
CJ1 \\
CJ7
\end{tabular} & NP1-wa----NP2-ni (yotte)----V-tr-areru \\
\hline A8 & NP1----di-V-tr & CJ8 & NP1-wa-----V-tr-areru \\
\hline A9 & NP1----di-V-tr-----(oleh)-NP2 & Active & NP1-wa,---NP2-ga-----V-tr. \\
\hline A10 & NP1----di-V-ditr----NP3---oleh-NP2 & CJ9 & NP1-wa----NP2-ni---NP3-wo---V-dit-areru \\
\hline A11 & NP1----di-V-ditr----dariNP2----pada-NP3 & $\mathrm{CJ} 10$ & NP1-wa----NP2-kara---NP3-ni----V-ditr-areru \\
\hline A12 & NP1---di-V-tr---(dengan)-NP3---oleh NP3 & CJ11 & NP1-wa----NP2-ni---NP3-to---V-tr-areru \\
\hline \multirow[t]{2}{*}{ A13 } & \multirow[t]{2}{*}{ NP1----ditinggal-V-intr-----(oleh)-NP2 (----ke-NP3). } & KJ5 & NP1-wa-----NP2-ni----V-intr-areru \\
\hline & & KJ8 & NP1-wa-----NP2-ni-----(NP3-e----)-V-intr-areru \\
\hline B1 B3 & NP1-----NP2-V-tr. & Active & NP1-wa,----NP2-ga-----V-tr. \\
\hline $\mathrm{C} 1$ & NP1-----ter-V-tr-----(oleh)-NP2 & CJ1 & NP1-wa-----NP2-ni----V-tr-areru \\
\hline $\mathrm{C} 2$ & NP1-----ter-V-tr-----(oleh)-NP2 & Active & NP2-wa-----NP2-niwa---V-tr-areru (kanou) \\
\hline D1 & NP1-----ke-NP2-an & KJ4 & NP1-wa-----NP2-ni----V-intr-areru \\
\hline D2 & NP2-----ke-V-an----(oleh)-NP2. & Active & NP1-ga------V-intr \\
\hline E1 & NP1-----kena-NP2 & KJ1 & NP1-wa-----NP2-ni----V-intr-areru \\
\hline E2 & NP1-----kena-V-----NP2 & $\mathrm{CJ1}$ & NP1-wa------NP2-ni---V-tr-areru \\
\hline
\end{tabular}

Table 3 shows that the Indonesian passive sentence A9, B1 B3, C2, and D2 types cannot be paired into Japanese 
passive sentences. These types lead Indonesian students of Japanese to make mistakes in understanding Japanese sentence structures.

\section{Conclusion}

This paper presents the results of a contrastive analysis of Indonesian and Japanese passive sentence structures. It can be concluded that Japanese direct passive sentences with predicates consisting of a transitive or ditransitive verb can be paired into the di-V passive construction in Indonesian. However, most indirect passive sentences could not be paired into Indonesian passive sentences, with exceptions for the $\mathrm{KJ1}, \mathrm{KJ} 4, \mathrm{KJ} 5$ and $\mathrm{KJ} 8$ types. Meanwhile, the Indonesian passive sentences that cannot be paired into Japanese passive sentences are the A9, B1 B3, C2, and D2 types, and they can only be paired into active sentences. The types of passive sentences that cannot be paired could lead the Japanese language learners in Indonesia to make errors in their use of these sentence types. Finally, it is necessary to perform follow-up efforts to organize the structure of Japanese passive sentence learning materials in Indonesia in order to revise the existing teaching materials.

\section{References}

Alwi, Hasan, et.al. 2006. Tata Bahasa Baku Bahasa Indonesia (Edisi III, cetakan VI), Jakarta: Balai Pustaka.

Hasegawa, N. (1999). Seisei Nihongo-gaku. Tokyo: Taishuukan Shoten.

Kaswanti, P. B. (1984). Dieksis dalam Bahasa Indonesia. Jakarta: Balai Pustaka.

Kaswanti, P. B. (1986). 'Analisis wacana men- dan di- Bahasa Indonesia'. Kaswanti, P. B. (Ed.) Pusparagam Linguistik \& Pengajaran Bahasa. Jakarta: Arcan.

Kaswanti, P. B. (1989). Serpih-Serpih Telaah Pasif BI, Jakarta: Kanisius.

Kaswanti, P. B. (2000). 'Konstruksi Pasif Bahasa Indonesia'. Kongres Bahasa Indonesia V: Menjunjung Bahasa Indonesia sebagai Bahasa persatuan dalam Konteks Pembangunan I. Jakarta: Departemen Pendidikan dan Kebudayaan.

Kridalaksana, H. (1986). 'Perwujudan Fungsi dalam Struktur Bahasa'. Linguistik Indonesia, 4, 7. Jakarta: MLI.

Kridalaksana, H. (2002). Struktur, Kategori, dan Fungsi dalam Teori Sintaksis. Jakarta: Universitas Katolik Atma Jaya.

Muraki, S. (1996). Nihongo Doushi no Shosou. Tokyo: Hitsuji Shobou.

Muraki, S. (2004). 'Kaku', Nitta, et.al. (Ed). Bun no Kokkaku.Tokyo: Iwanami Shoten.

Nakano, H. (2012). Asakura Nichi-ei Taishou Gengogaku Shiriizu 6: Imiron. Tokyo: Asakura Shoten.

Nitta, Y. (1979). Nihongo Bunpou Kenkyuu Josetsu: Nihongo Kijutsu Bunpou wo Mezashite. Tokyo: Kuroshio Shuppan.

Nitta, Y. (2011). Gendai Nihongo Bunpou 2: Kaku to Koubun \& Boisu. Tokyo: Kuroshio Shuppan.

Sugono (1991). Berbahasa Indonesia dengan Benar. Jakarta: Priastu

Sutedi, D. (2006). 'Indoneshiago no DI-doushi Koubun to Nihongo no RARERU to no Taishou Kenkyuu', Nihon Gengo Bunka Kenkyuukai Ronshuu(Journal of Japanese Language and Culture), 2.

Sutedi, D. (2012). 'Klasifikasi Kalimat Pasif Instrasitif dalam Bahasa Jepang Berdasarkan Peran Semantisnya'. Kajian Linguistik dan Sastra Vo 24, No. 2.

Sutedi, D. (2013). 'Tipe-tipe Kalimat Pasif Murni dalam Bahasa Jepang Berdasarkan Kategori dan Peran Sematisnya'. Humaniora Vol 25, No.3

Takahashi, T. (2006). Nihongo no Bunpou. Tokyo: Hitsuji Shobou.

Takami, K. (1997). Kinouteki Koubunron ni yoru Nichi-Eigo Hikaku: Ukemibun, Kouchibun no Bunseki. Tokyo: Kuroshio Shuppan.

Takami, K. (2011). Ukemi to Shieki. Tokyo: Kaitakusha.

Tanaka, M. (1991) 'Indonesiahiago wo Bogo to Suru Gakusuusha no sakubun ni Arawareru 'Ukemi' ni Tsuite no Kousatsu'. Nihongo Kyouiku Gakkai, No.74

Teramura, H. (2002). Nihongo no Shintakusu to Imi I. Tokyo: Kuroshio Shuppan.

Tsunoda, T. (1991). Seikai no Gengo to Nihongo: Gengo Ruikeiron kara Mita Nihongo. Tokyo: Kuroshio Shuppan.

Verhaar, J. W. M. (1982). Pengantar Linguistik Jilid I. Yogyakarta: Gadjah Mada University Press.

Verhaar, J. W. M. (2004). Asas-Asas Linguistik Umum. Yogyakarta: Gadjah Mada University Press. 